\title{
KEDUDUKAN HAKIM WANITA DALAM PERSPEKTIF FUQAHĂ’ (Studi Komparatif Imām Abū Han̄ifah dan Ibn Jarīr At-Thabarī)
}

\author{
Siti Mualifah, Adang Djumhur Salikin, Ubaidillah, \\ Fakultas Syariah dan Ekonomi Islam \\ Institut Agama Islam Negeri Syekh Nurjati Cirebon \\ Email: mualifahdemak@gmail.com
}

\begin{abstract}
Abstrak
Hakim merupakan salah satu profesi yang sangat urgen, karena hakim adalah salah satu jabatan yang tinggi dalam islam. Kedudukan ini lebih tinggi jika dibandingkan dengan mufti, karena tugas hakim bukan hanya sekedar menyatakan hukum, melainkan juga menjatuhkan suatu hukuman yang mana hasil dari putusan tersebut wajib dilaksanakan dan dipatuhi. Sehingga syarat-syarat dan uji kelayakan harus ditegakkan secara demokratis, adil, dan jujur. Dalam wacana syarat-syarat dan status keabsahan wanita menjabat sebagai hakim, di kalangan fuqaha terjadi perbedaan pendapat dan menimbulkan kontroversi di kalangan imam madzhab.Penelitian ini bertujuan untuk menjawab dari pertanyaanpertanyaan yang menjadi rumusan masalah: "Bagaimana pendapat Abū Hanīfah dan Ibn Jarīr At-Thabarī mengenai kedudukan hakim wanita, bagaimana persamaan dan perbedaan pendapat Abū Hanīfah dan Ibn Jarīr At-Thabarī tentang kedudukan hakim wanita serta bagaimana relevansi pendapat kedudukan hakim wanita dalam konteks keIndonesiaan antara Abū Hanīfah dan Ibn Jarīr At-Thabarī”. Penelitian ini menggunakan penelitian kualitatif (kepustakaan), sifat penelitian yang digunakan adalah deskriptif-analisis komparatif, yaitu dengan menggambarkan masalah-masalah yang terkait serta mengkomparasikan pendapat dari dua tokoh madzhab.Kesimpulan penelitian ini adalah menurut Abū Hanīfah wanita dapat menjadi hakim hanya dalam masalah perdata (mu'amalah) bukan dalam masalah pidana (qishās dan hudūd), sebagaimana mengqiyaskan kebolehan seorang wanita menjadi saksi begitupula kebolehan wanita menjadi hakim. sedangkan menurut Ibn Jarīr At-Thabarī wanita boleh menjadi hakim secara mutlak untuk semua perkara, sebagaimana Ibn Jarī AtThabarī menganalogikan wanita boleh mengeluarkan fatwa yang dianggap sah sehingga dalam hal ini wanita boleh menjadi hakim dan keputusannya pun dianggap sah. Adapun Letak persamaan pandangan Abū Hanīfah dan Ibn Jarīr At-Thabarī dalam hal status wanita menjabat sebagai hakim yaitu keduanya sama-sama tidak menjadikan laki-laki sebagai syarat sahnya pengangkatan seorang hakim. sedangkan Letak perbedaan pendapat antara keduanya adalah kewenangan hakim perempuan dalam memutuskan perkara pada wilayah peradilan, Abü Hanīfah membatasi kewenangan wanita dalam memutuskan perkara hanya pada wilayah perdata tidak pada hudūd dan qishās. Selain itu Abū Hanīfah juga berpendapat bahwasannya barang siapa yang mengangkat seorang wanita menjadi hakim maka ia berdosa. Sedangkan Ibn Jarīr At-Thabarī memperbolehkan wanita menjabat sebagai hakim secara mutlak dan terkait pengangkatannya pun secara mutlak ia memperbolehkan. Di antara pendapat kedua imam tersebut yang paling relevan di Indonesia adalah pendapat Ibn Jarīr At-Thabarī yang sesuai dengan jiwa masyarakat Indonesia saat ini.
\end{abstract}

Kata Kunci : Hakim Wanita, Abū Hanīfah, Ibn Jarīr At-Thabarī 


\begin{abstract}
Judges are a very urgent profession, because judges are one of the highest positions in Islam. This position is higher when compared to the mufti, because the task of the judge is not just to declare the law, but also to impose a sentence in which the results of the decision must be implemented and obeyed. So that the requirements and due diligence must be upheld in a democratic, fair and honest manner. In the discourse on the terms and legal status of women serving as judges, there was a difference of opinion among the jurists and caused controversy among the Imams of the schools. This study aims to answer the questions that formulate the problem: "What is the opinion of Abū Hanifah and Ibn Jarīr At-Thabari regarding the position of female judges, how the similarities and differences in opinion of Abu Hanīfah and Ibn Jarīr at-Thabari regarding the position of female judges and how relevant opinion of the position of female judges in the Indonesian context between Abü Haniffah and Ibn Jarīr at-Thabarī ". This study uses qualitative research (literature), the nature of the study used is comparative descriptive analysis, that is by describing the problems associated with and comparing the opinions of two school leaders. The conclusion of this research is that according to Abü Hanïfah, women can be judges only in civil matters (mu'amalah) not in criminal matters (qishās and hudūd), as is the assertion of the ability of a woman to be a witness and the ability of a woman to be a judge. whereas according to Ibn Jarìr at-Thabari women may be absolute judges for all cases, as Ibn Jarìr at-Thabarī analogizes that women may issue fatwas that are considered valid so that in this case women may be judges and their decisions are considered valid. As for the location of the similarity of the views of Abu Hanifah and Ibn Jarìr at-Thabari in terms of the status of women serving as judges that both do not make men the legal requirement for the appointment of a judge. Whereas the difference of opinion between the two is the authority of women judges in deciding cases in the jurisdiction, Abü Haniffah limits the authority of women in deciding cases only in the civil domain not in hudūd and qishās. In addition, Abū Hanīfah also believes that whoever appoints a woman to be a judge is a sinner. Whereas Ibn Jarìr at-Thabari allowed women to serve as judges absolutely and related to his appointment he absolutely allowed. Among the opinions of the two imams which is most relevant in Indonesia is the opinion of Ibn Jarir AtThabari which is in accordance with the spirit of the Indonesian people today.
\end{abstract}

Keywords: Female Judge, Abū Hanīfah, Ibn Jarīr At-Thabarī 


\section{A. PENDAHULUAN}

Perbincangan tentang perempuan dalam Islam selalu berujung pada kesimpulan bahwa Islam tidak ramah perempuan. Posisi perempuan yang ramah dan inferior tergambar jelas dalam fakta empiris di masyarakat islam maupun dalam lembaran-lembaran keislaman. ${ }^{1}$

Dalam hakikatnya, wanita muslimah adalah mitra kerja pria dalam memakmurkan bumi sesempurna mungkin. Wanita haruslah ikut serta dengan serius dan terhormat dalam berbagai lapangan kehidupan. Mengingat lapangan kehidupan itu lazimnya tidak lepas dari keberadaan laki-laki, bahkan kaum laki-lakilah yang menguasai mayoritas peranan penting dalam masyarakat, syariat Allah tidak menghalangi wanita bertemu dengan lakilaki dan melihatnya. Atau sebaliknya, begitu pula dalam berbicara, bertukar pikiran, atau bekerja sama untuk mengerjakan suatu pekerjaan dengan catatan mereka tetap memperhatikan ketentuan-ketentuan agama. ${ }^{2}$

Nabi saw. sangat memahami peran wanita dalam mempermudah dan membantu berbagai usaha kebaikan. Penyalahgunaan kondisi tersebut sama artinya dengan mempersulit dan mempersempit ruang gerak wanita sekaligus menghalanginya dari melakukan kebaikan. Namun, ada yang harus diperhatikan bahwa kebebasan tersebut tidak lantas melalaikan seorang wanita muslimah dari pelaksanaan tugas dan tanggung jawab terhadap rumah tangga dan anak-anaknya.

Bahkan, kiprahnya dalam kehidupan sosial akan membantu wanita dalam pematangan kepribadian dan agar mampu melaksanakan berbagai kegiatan yang

1 Siti Musdah Mulia, Islam \& Inspirasi Kesetaraan Gender, (Jakarta: Kibras Press, 2007), 13

${ }^{2}$ Abdul Hakim Abu Suqqyah, Kebebasan Wanita, (Jakarta: Gema Insani Press, 1997), 1 membutuhkan perannya, baik menyangkut keperluan keluarga atau keperluan masyarakat. $^{3}$

Sejak dahulu keikutsertaan wanita dalam aktifitas sosial dan pertemuannya dengan laki-laki, baik secara kebetulan ataupun disengaja untuk tujuan yang baik, sudah merupakan corak kehidupan yang umum dalam masyarakat muslim dalam bidang umum dan khusus. ${ }^{4}$

Dalam konteks Bahasa Indonesia, sebenarnya kata "gender" ini tidak mempunyai padanan yang tepat maknanya, oleh karena itu istilah "Gender" seringkali disalah artikan. Kamus Bahasa Inggris yang ditulis John Echols dan Hasan Sadly, misalnya, memakai gender dengan "jenis kelamin". Realita yang sama juga ditemukan dalam kamus-kamus lainnya seperti The Advance Learner's of Current English, yang mendefinisikan gender sebaga ciriciri biologis yang membedakan jenis kelamin laki-laki dan perempuan. Dalam kehidupan sehari-hari konsep gender juga disalah artikan sebagai kata yang merujuk kepada perempuan, sehingga seringkali pejabat yang merekomendasikan hanya karyawan perempuan untuk menghadiri terkait isu gender. Dokumen-dokumen yang terkait dengan identitas pribadi seringkali mengggunakan kata gender dan seks tanpa perbedaan yang jelas. Gender dapat dimaknai sebagai kontruksi sosial tentang pembedaan sifat, peran, tanggung jawab, nilai, perilaku, mentalitas, dan karakteristik emosional laki-laki dan perempuan. Dewasa ini, terjadi pembakuan pemahaman yang keliru di masyarakat, gender yang menjadi konstruksi sosial justru dianggap sebagai kodrat (ketentuan Tuhan). Misalnya urusan domestik seperti mendidik anak, memasak, megatur pengeluaran rumah tangga, atau urusan domestik lainnya

\footnotetext{
${ }^{3}$ Abdul Hakim Abu Suqqyah, Kebebasan Wanita,..., $1-2$

${ }^{4}$ Abdul Hakim Abu Suqqyah, Kebebasan Wanita,..., 3
} 
sering dianggap sebagai "kodrat perempuan". Faktanya, aktivitas domestik kontruksi sosial yang bisa dilakukan baik oleh kaum laki-laki atau perempuan, karena pekerjaan-pekerjaan domestik dapat dipertukarkan. ${ }^{5}$

Salah satu masalah yang seringkali menjadi perdebatan sengit negara-negara Islam atau penduduknya yang mayoritas Islam adalah masalah kepemimpinan perempuan. Walaupun pada realitas sudah ada pemimpin perempuan seperti Begum Khalida Zia di Bangladesh, Benazir Bhutto di Pakistan, Gloria Macpagal Arroyo di Filipina dan Megawati Soekarno Putri di Indonesia, tetapi pada tataran pemikiran persoalan ini belum dianggap selesai. Banyak faktor yang menyebabkannya, disamping persoalan pemahaman keagamaan. Faktor politik juga sangat kental mewarnai. Bahkan ada kecenderungan untuk membiarkan persoalan ini bisa dijadikan kampanye politik untuk menolak ini bisa dijadikan kampanye politik untukmenolak kepemimpinan perempuan dengan argumen agama.

Kewajiban umum kaum perempuan terhadap masyarakat adalah sama dengan kewajiban kaum laki-laki. Laki-laki dan perempuan sama-sama memikul kewajiban serta tanggung jawab untuk kesejahteraan dan kemaslahatan masyarakatnya. Dalam beberapa hal, bukan saja laki-laki memimpin perempuan, tetapi perempuan juga memipin laki-laki. ${ }^{6}$

Di antara tugas bersama dengan lakilaki dan perempuan adalah menegakkan kebenaran dan keadilan serta mengokohkan akhlak yng mulia dan budi pekerti yang luhur dalam masyarakat. Juga mereka sama-sama berkewajiban dalam mencegah perbuatan yang mungkar

${ }^{5}$ Hermawati Ida Rosyidah, Relasi Gnder Dalam Agama-Agama, (UIN Jakarta press. 2013), 43.

Dalam Islam, 1 yang merusak akhlak dan mengacaukan ketenteraman, menghilangkan nilai dan mutu masyarakat. Ini berlaku untuk segala macam kegiatan, tidak terkecuali di bidang politik dan kenegaraan, termasuk dalam bidang penegakan hukum di lembaga peradilan.

Indonesia, dalam hal ini memiliki apa yang disebut peradilan agama yang memiliki tugas dan kewenangan untuk meninjau, memutuskan dan menyelesaikan kasus-kasus untuk warga negara beragama Islam untuk masalah pernikahan, warisan, dan ekonomi syariah. Peradilan ini dibentuk oleh undang-undang dengan wilayah yuridiksi kabupaten dan kota. Pengadilan Agama tingkat Tinggi memiliki provinsi sebagai wilayah yuridiksinya. Menurut Kementrian Agama, peradilan agama ini memiliki 675 (24 persen) hakim perempuan diantara total 3.390 hakim peradilan agama. Tidak ada satu orangpun yang bekerja di mahkamah konstitusi dari tahun 2003-2008 dan hanya satu orang perempuan yang dimasukkan ke dalam daftar sembilan orang hakim mahkamah konstitusi yang memegang peranan penting dalam peninjauan kembali berbagai perundang-undangan yang deskriminatif. Karenanya penting meningkatkan keterwakilan perempuan di mahkamah kontitusi. ${ }^{8}$

Kemudian ditinjau dari segi yuridis kedudukan hakim wanita terkait pula dengan sejarah peraturan dan perundangundangan tentang kekuasaan kehakiman. Peluang bagi hakim perempuan di Peradilan Agama baru terbuka setelah dikeluarkannya Undang-undang Nomor 1 Tahun 1974 tentang Perkawinan dan Undang-undang Nomor 7 Tahun 1989 Tentang Peradilan Agama. Singkatnya,

\footnotetext{
7 Huzaemah Tahido Yonggo. Fikih Perempuan Kontemporer. Penerbit Ghala Indonesia. Bandung. 2010. 99-100.

UNDP INDONESIA. Partisipasi Perempuan dalam Politik dan Pemerintahan. UNDP Indonesia. Mei 2010. 16-17.
} 
sebelum keluar dua perundang-undangan tersebut, peluang perempuan untuk menjadi hakim tampaknya belum terakomodasi baik dari segi regulasi maupun kompetensinya.

Setelah keluarnya UUPA Nomor 3 Tahun 2006 jo. Diamandemen dengan UUPA Nomor 50 Tahun 2009 kuantitas hakim perempuan mengalami peningkatan dibandingkan dengan hakim laki-laki yang notabene jumlah hakim laki-laki sebelumnya sudah cukup banyak dibandingkan dengan hakim perempuan. Adapun fenomena yang untuk diangkat dalam tulisan ini adalah saat ini ada peluang yang sangat lebar bagi perempuan untuk berkiprah baik pada ranah lembaga yudikatif maupun lembaga lainnya, termasuk di dalamnya menjadi hakim di Pengadilan Agama. ${ }^{9}$

Masalah boleh tidaknya wanita menjadi hakim, sampai saat ini masih mengalami perbedaan pendapat di kalangan ulama fiqh. Hal ini tidak terlepas adanya perbedaan dalam memahami Hadis Riwayat Imam Bukhari. Ada ulama yang berpendapat bahwa wanita tidak boleh menjabat secara mutlak, adapula yang berpendapat boleh dalam kasus tertentu dan tidak boleh dalam kasus lainnya, dan ada juga yang membolehkan secara mutlak dalam kasus apapun. Menurut jumhur ulama, Imam Malik, Imam Syafi'i, Imam Ahmad, wanita tidak boleh menjabat sebagai hakim. dasar pendapat mereka adalah Q.S. An-Nisā' ayat 34, hadis Rasulullah yang mengatakan "bahwa tidak akan bahagia suatu kaum yang menyerahkan urusan mereka pada wanita". (HR. Bukhari), Hadis yang menyatakan "bahwa akal dan keberagaman wanita kurang dibanding

\footnotetext{
${ }^{9}$ Djazimah Muqoddas, Kontribusi Hakim Perempuan dalam penegakan hukum di Indonesia, (jurnal Mahkamah Agung RI, Asyari'ah vol. 17 no 2, Agustus 2015), 94.
}

akal dan keberagaman pria." (HR. Ibnu Majah). ${ }^{10}$

Adapun yang mendukung penolakan wanita menjadi hakim secara mutlak mengatakan bahwa perempuan dilarang menjadi qadhi (yudikatif) menurut syara', sebab profesi ini menuntut kesempurnaan pendapat (olah fikir), padahal wanita pada umumnya lemah akalnya, di mana Rasulullah Saw menafsirkan sifat ketidaksempurnaan akalnya ini bahwa kesaksian wanita adalah setelah dari kesaksian laki-laki. ${ }^{11}$

Peran sosial perempuan dalam lintas sejarah Islam mengalami kemunduran di abad kedua, setelah penguasa muslim kembali mengintrodusir tradisi Hellinistik di dalam dunia pemerintahan. Di samping itu para ulama di antaranya dengan sponsor pemerintah, sedang giat-giatnya melakukan standarisasi hukum dengan melaksanakan kodifikasi kitab-kitab fikih dan kitab-kitab hadis. Tentang apakah ada kaitannya antara pembukuan dan pembakuan kitab fikih dan proses penuruan peran perempuan, ternyata sejumlah penelitian memberikan jawaban positif, bahwa ada konsep superioritas laki-laki atas perempuan banyak dipengaruhi oleh unsur pembukuan kitablitan fikih klasik. Namun demikian, ada juga ilmuan yang melihat adanya kesan superioritas laki-laki dari perempuan dalam kitab-kitab fikih disebabkan oleh tuntutan masyarakat dan cara berfikir ulama mazhab pada saat itu. ${ }^{12}$

Kitab-kitab fikih amat dipengaruhi oleh lingkungan penulisnya yang berbedabeda. Penulis yang hidup di lingkungan masyarakat di mana kekuasaan kaum lakilakinya dominan (male dominated society), seperti di kawasan Timur

${ }^{10}$ Salim Ali Bahnasawi, Wawasan Sisten Politik Islam, (Jakarta: Pustaka Al-Kautsar, 1996), 293-294.

${ }^{11}$ Salim Ali Bahnasawi, Wawasan Sisten Politik Islam, (Jakarta: Pustaka Al-Kautsar, 1996), 293-294.

12 Khairudin Nasution, Fazlur Rahman Tentang Wanita, (Yogyakarta: Tazzafa, 2001), 43. 
Tengah, banyak tulisan dan buku-buku yang bercorak patriarkhi, benar dikatakan bahwa ada hukum-hukum particular yang menetapkan sejenis kesenjangan antara laki-laki dan perempuan. ${ }^{13}$

Terkait dengan pendirian ulama seputar kebolehan mengangkat hakim berjenis kelamin wanita, Ali bin Nayif asy-Syuhud memetakan menjadi 3 kelompok. Pertama: melarang secara mutlak, ini adalah pendirian jumhur ulama dari kalangan Malikiyah, Syafi'iyah dan Hanabilah. Kedua: membolehkan namun terbatas dalam persoalan perdata, ini adalah pegangan mazhab Hanafiyah. Ketiga : membolehkan secara mutlak, ini dikemukakan oleh Ibnu Hazm az-Zhahiri serta Ibnu Jarīr at-Thabari ${ }^{-14}$

Terlepas dari kutipan salah seorang ulama di atas tentang keabsahan seorang hakim perempuan, penulis merasa sangat perlu memaparkan lebih jauh bagaimana polemik serta komentar serta argumentasi yang digunakan para ulama lain tentang keabsahan hakim perempuan.

Berdasarkan masalah ini kiranya perlu dipertanyakan bagaimana sesungguhnya kedudukan hakim wanita ditinjau menurut fuqahā' menurut pendapat Imām $A b \bar{u}$ Hanīfah dan Ibnu Jarīr at Thabarī dan alasan-alasan yang dipergunakan. Secara umum penelitian dimaksudkan untuk menggambarkan secara utuh argumen ulama menganai boleh tidak wanita menjadi hakim di pengadilan.

Berdasarkan uraian di atas, penulis ingin mengetahui dan meneliti lebih dalam serta mengurai komparasi antara kedudukan hakim wanita menurut Imām Abū Hanīfah dan Ibnu Jarīr at-Thabarī. Kemudian hasil penelitian tersebut akan penulis tuangkan dengan judul

13 Muhammad Abed al-Jabiri, Syura' Tradisi Partikularitas Universalitas. Cet. ke-1, (Yogyakarta: LkiS, 2003), 177.

${ }^{14}$ Ali Trigiyatno, Pandangan Ibnu Jarir at-Thabari tentang kedudukan Wanita sebagai Hakim dan Imam Sholat,(Muwazah, volume 6, nomor 2, Desember 2014), 214.
"Kedudukan Hakim Wanita dalam Perspektif Fuqahā' "(Studi Komparatif Imām Abū Hanīfah dan Ibnu Jarīr atThabarī)".

\section{B. PENELITIAN TERDAHULU}

Berikut ini penelitian yang terkait judul Pertama penelitian saudara, Abdul Rochim, dengan judul. "Hakim Perempuan Perspektif Imam Abu Hanifah dan Imam Asy-Syafi'i”, penenelitian ini menyatakan bahwa penulis mencari relevansi pendapat antar kedua Imam madzab (Imam Abu Hanifah dan Imam as-Syafi'i), sesuai konteks keindonesiaan, serta sesuai dengan falsafah undang-undang kehakiman di Indonesia adalah pendapatnya imam Abu Hanifah serta modifikasi hukum yang sesuai dengan jiwa masyarakat Indonesia saat ini.

Dan yang kedua penelitian Puthut Syahfaruddin, "Kedudukan Hakim Perempuan Studi Komparatif Imam Abu Hanifah Dan Ibn Hazm" hasil penelitian ini yaitu fakor yang melatar belakangi terjadinya perbedaan pendapat antara Imam Abu Hanifah dan Ibnu Hazm disebabkan oleh perbedaan penafsiran terhadap ayat alQur'an dan hadis Nabi SAW, adapun persamaan keduanya dalam hal kedudukan hakim perempuan yaitu diperbolehkannya seorang perempuan menjabat sebagai hakim dan keduanya sama-sama tidak menjadikan laki-laki sebagai syarat mutlak untuk menjadi hakim. Sedangkan perbedaan pendapat mereka yaitu apabila Imam Abu Hanifah membatasi kewenangan hakim perempuan hanya pada wilayah perdata, berbeda pendapat dengan Ibn Hazm yang memperbolehkan perempuan menjabat sebagai hakim secara mutlak.

Peneleitian ketiga, penelitian saudara Luqman Bin Abdul Hamid, "Hakim Wanita (Studi Komperatif Antara Mazhab Hanafi Dan Mazhab 
Syafi'i)", penulis meneliti bagaimana analisa hukum antara kedua mazhab mengenai hakim wanita, bagaimana kedua mazhab menguraikan maksud daripada hadits Nabi SAW mengenai hakim wanita.

Berdasarkan penelitian-penelitian terdahulu yang membedakan dengan penelitian penulis adalah penelitian terdahulu tidak membahas pendapat imām Ibn Jarīr at-Thabarī serta relevansi pendapat kedua imam madzab pada konteks keindonesiaan sementara pembahasan penulis lebih menekankan pada pendapat Ibn Jarīr at-Thabarī dan juga relevansi pendapat kedua imam madzab untuk konteks keIndonesiaan.

\section{METODE PENELITIAN}

Metode penelitian yang penulis gunakan dalam penelitian ini adalah sebagai berikut:

1) Jenis Penelitian

Jenis penelitian ini adalah penelitian kepustakaan ( library research), maka peneliti menggunakan teknik yang diperoleh dari perpustakaan dan diperoleh dari buku-buku tersebut yaitu hasil membaca dan mencatat dari buku ilmiah yang berkaitan dengan pembahasan dan permasalahannya. Oleh karena jenis penelitian ini adalah studi kepustakaan, maka semua data penelitian ini baik data primer maupun sekunder mendasarkan pada data-data kepustakaan.

2) Pendekatan Penelitian

Pendekatan dalam penelitian ini adalah pendekatan Ushul Fiqih serta menganalisis istinbath hukum yang digunakan oleh Imām Abū Hanīfah dan Ibn Jarīr at-Thabarī secara sistematis dan objektif, dengan cara mengumpulkan data dan menganalisis dengan membandingkan dalil-dalil yang dipakai oleh Imām Abū Hanīfah dan Ibn Jarīr at-Thabarī guna mendapatkan kesimpulan akhir dalam menemukan persamaan dan perbedaan pendapat antara Imām Abū Hanīfah dan Ibn Jarīr atThabarī serta apa saja faktor yang melatar belakangi terjadinya perbedaan pendapat tersebut.

3) Sumber Data

a. Sumber Data Primer

Sumber primer adalah sumber data yang diperoleh secara langsung dari objek penelitian. Sumber primer yang penulis gunakan yaitu sumber data tertulis mengenai hal-hal yang membahas tentang hakim wanita itu sendiri menurut pandangan Abū Hanīfah dan Ibnu Jarīr at-Thabarī, berupa buku-buku yang akan membahas hal-hal yang berkaitan dengan kedudukan hakim wanita menurut Abū Hanīfah dan Ibnu Jarīr atThabarī.

b. Sumber Data Sekunder

Sumber sekunder adalah data yang diperoleh lewat pihak lain, tidak langsung diperoleh oleh peneliti dari subyek penelitiannya. Sumber-sumber sekunder yang penulis kumpulkan untuk mendapatkan data-data dalam penyusunan skripsi ini adalah kitab-kitab fiqh, qawaid fiqhiyyah, serta tulisan-tulisan berupa jurnal, artikel yang relevan dengan masalah yang dibahas.

4) Metode Penelitian Data

Metode pengumpulan data yang digunakan dalam skripsi ini menggunakan metode dokumentasi, yang disebut metode dokumentasi adalah merupakan suata alat pengumpulan data yang dilakukan melalui tertulis. Oleh 
karena itu, penulis mengumpulkan referensi-referensi yang berkaitan dengan topik pembahasan.

5) Metode Analisis Data

Adapun metode yang dipakai dalam menganalisis data menggunakan content analysis dan komparatif, yakni menganalisis dan memahami isi kitab-kitab fiqih tradisional (klasik) dan sejumlah data yang berbeda-beda dengan cara membandingkan antara data yang satu dengan data lainnya.,untuk sampai pada satu titik kesimpuan. Selain dari pada itu, tujuan analisis ini adalah untuk menjelaskan perbedaan dan persamaan di antara Imam Abu Hanīfah dan Ibn Jarīr at-Thabarī dan kemudian menganalisis faktorfaktor yang melatarbelakangi terjadinya perbedaan dan persamaan pendapat.

\section{PEMBAHASAN}

\section{Pengertian Hakim}

Hakim merupakan salah satu profesi yang sangat urgen, karena harus menyelesaikan gugatan sengketa dan konflik yang terjadi di tengah-tengah kehidupan manusia sesuai dengan hukum yang berlaku di suatu negara, sehingga syarat-syarat kekuasaan kehakiman Islam dan kekuasaan kehakiman yang ada di Indonesia ada sedikit signifikasi perbedaan, yaitu masalah kedudukan wanita menjadi hakim. kaum perempuan pada masa sebelum Islam (Jahiliyah) mendapat kedudukan yang rendah, hina, memalukan, oleh agama Islam diangkat derajatnya menjadi lebih baik, terhormat, dan berharga. Agama Islam datang dengan membawa pembaharuan bagi kedudukan kaum perempuan. ${ }^{15}$

15 Abdul Rochim, Hakim Perempuan; Perspektif Imam Abu Hanifah dan Imam AsSyafi' $i, 2$.
Dalam Kamus Besar Bahasa Indonesia disebutkan bahwa perempuan adalah jenis kelamin yakni orang atau manusia yang memiliki rahim, mengalami menstruasi, hamil, melahirkan dan menyusui. Dalam ensiklopedia Islam, kata perempuan berasal dari bahasa Arab alMar'ah, jama' dari kata al-Nisā sama dengan wanita, perempuan dewasa atau putri dewasa yaitu lawan jenis pria. $^{16}$ Memahami pengertian perempuan tentunya tidak bisa lepas dari persoalan fisik dan psikis. Perempuan dalam konteks psikis atau gender didefinisikan sebagai sifat yang melekat pada seseorang untuk menjadi feminis. Sedangkan perempuan dalam pengertian fisik merupakan salah satu jenis kelamin yang ditandai oleh alat reproduksi berupa rahim, sel telur dan payudara sehingga perempuan dapat hamil, melahirkan dan menyusui. Pembicaraan tentang perempuan pada masa lalu berkisar pada penggambaran kecantikan fisik dan moral saja, kemudian setelah itu dikatakan bahwa tugas perempuan dianggap sebagai anggota keluarga yang hanya mengurus urusan belakang, tidak boleh tampil di depan. Seberapa banyak uang yang di dapat, tidak akan pernah dianggap pencari nafkah. ${ }^{17}$

Hakim berasal dari kata dalam bahasa Arab yaitu hakimun yang diambil dari akar kata hakama-yahkumu-hakaman yang artinya memimpin, memerintah, menetapkan, memutuskan. Al-hakīmu bisa diartikan sebagai hakim pengadilan, bisa juga diartikan orang yang arif, orang yang bijaksana. Ada juga yang diartikan sebagai orang yang teliti, orang yang tepat, orang yang sempurna. ${ }^{18}$

16 Tim Penyusun Kamus Pusat Bahasa, Kamus Besar Bahasa Indonesia, (Jakarta: Balai Pustaka, cet. 2, ed.3, 2002), 856.

17 Murtadha Mutahhari, Hak-Hak Perempuan dalam Islam, (Jakarta: Lentera Baritama, 1995), 74.

18 Munawwir, Ahmad Warson, Kamus al-Munawwir Arab-Indonesia, (Surabaya: Pustaka Progresif, 1997), 286-287. 
Senada dengan pendapat Muhammad Salam Madkur, Muhammad Hasbi Ash-Shidiqie memberikan pendapatnya mengenai definisi hakim yaitu orang yang diangkat oleh kepala negara untuk menyelesaikan gugatan, perselisihan-perselihan dalam bidang perdata, oleh karena penguasa sendiri tidak dapat menyelesaikan tugas peradilan ${ }^{19}$. Adapun menurut UU RI No. 7 tahun 1989 tentang Peradilan Agama disebutkan bahwa hakim adalah pejabat yang melaksanakan tugas kekuasaan kehakiman. $^{20}$

Dari ketiga definisi di atas dapat disimpulkan bahwa hakim adalah seseorang yang ditunjuk oleh pemerintah untuk menangani permasalahanpermasalahan yang berkaitan dengan persengketaan. Adapun tugas hakim yang paling pokok adalah menerima, memeriksa, dan mengadili serta menyelesaikan setiap perkara yang diajukan kepadanya. ${ }^{21}$ Lebih rinci alMawardi menyebutkan tugas hakim itu adalah sepuluh, ${ }^{22}$ di antaranya yaitu:

1) Memutus atau menyelesaikan perselisihan, pertengkaran dan konflik; dengan mendamaikan kedua belah pihak berperkara secara sukarela, atau memaksa keduanya berdamai;

2) Membebaskan orang yang tidak bersalah dari sanksi dan hukuman, serta memberikan sanksi kepada yang salah;

3) Menetapkan penguasaan harta benda orang yang tidak dapat

19 Teungku Muhammad Hasbi AshShiddiqie, Peradilan dan Hukum Acara Islam, (Semarang: Pustaka Rizki Putra, 1997), 39.

${ }^{20}$ Cik Hasan Bisri, Peradilan Agama di Indonesia, (Jakarta: PT Raja Grafindo Persada. 2000), 348

21 UU RI No. 14 tahun 1970 tentang ketentuan pokok kekuasaan kehakiman, Bab I pasal 2 ayat 1.

22 Jainal Arifin, Peradilan Agama dalam Bingkai Reformasi,164-165. menguasai sendiri karena gila, masih kanak-kanak atau idiot;

4) Mengelola harta wakaf dengan menjaga, mengembangkan, menahannya, dan mengalokasikan ke posnya;

5) Melaksanakan wasiat berdasarkan syarat pemberi wasiat dalam hal yang diperbolehkan syari'at dan tidak melanggarnya;

6) Menikahkan gadis-gadis dengan orang-orang sekufu (selevel), apabila mereka tidak mempunyai wali dan telah memasuki usia nikah.

7) Melaksanakan hudud kepada orang yang berhak menerimanya. Apabila menyangkut hak Allah Swt., ia melaksanakannya penggugat; apabila telah terbukti atas pengakuan dan barang bukti. Apabila menyangkut hak manusia, pelaksanaan hudud ditentukan oleh permintaan penggugat;

8) Memikirkan kemaslahatan umum, dengan melarang segala gangguan di jalan dan halaman rumah serta meruntuhkan bangunan-bangunan ilegal;

9) Mengawasi para saksi dan pegawainya, serta memilih orang yang mewakilinya. Apabila mereka jujur, kredibel dan istiqomah, ia mengangkatnya. Apabila mereka berkhianat, ia mengganti dengan pejabat baru;

10) Menegakkan persamaan di depan hukum antara orang yang kuat dan lemah, dan menegakkan keadilan dalam peradilan baik bagi orang bangsawan maupun rakyat biasa.

\section{Dasar Hukum Seorang Hakim}

Al-Qur'an telah meletakkan dasar asasi sebagai landasan dalam penegakan kebenaran dan keadilan di antara manusia. Adapun ayat-ayat yang terkait mengenai landasan menjadi hakim yaitu, QS An-Nisā/4: 135, dan alMāidah/5:8. 
Adapun dasar/landasan normatif lainnya yaitu tertera dalam peraturan perundang-undangan, yaitu Pemerintah No. 12 Tahun 1967 tentang Kehakiman. Kemudian ketentuan pokok kekuasaan kehakiman, terdapat dalam 10 Undang-undang No. 14 Tahun 1970 tentang KetentuanKetentuan Pokok Kekuasaan Kehakiman yang merinci tugas-tugas hakim di lingkungan peradilan, yaitu Peradilan Umum, Peradilan Agama, Peradilan Militer, dan Peradilan Tata Usaha Negara. Lebih lanjut tentang hal ini dapat dilihat dalam pasal 63 Undang-undang No. 1 Tahun 1974 tentang Perkawinan dan Undangundang No. 14 Tahun 1985 tentang Mahkamah Agung. ${ }^{23}$

\section{Sifat dan Syarat-Syarat Seorang Hakim}

Hakim merupakan orang yang bertanggung jawab sepenuhnya dalam menegakkan kebenaran dan keadilan. Oleh karena itu, Islam mensyaratkan dengan ketat untuk dapat diangkat menjadi seorang hakim (qadhi).

Mengenai syarat yang diperlukan terhadap seorang yang akan menjadi hakim, terdapat perselisihan pendapat oleh beberapa pakar hukum islam. AlRamli dalam kitabnya Nihāya alMuhlaj menyebutkan ada sepuluh syarat yang harus dimiliki oleh seorang qadhi. Pendapat ini didasarkan pada alImam al-Nawawi, yakni Islam, mukallaf, merdeka, lelaki, mendengar, melihat, berkata-kata, berkemampuan, dan mujtahid. Sedangkan al-Mawardi dalam bukunya $A l$ Ahkam Ash Shulthaniyyah wa Al-Wilayat AlDiniyyah mensyaratkan tujuh ketentuan yang harus ada pada seorang qadhi yakni, lelaki, berakal, merdeka,, Islam, adil, sempurna pendengaran dan penglihatan, menguasai bidang hukum

23 Muhammad Ali, Hakim dalam Perspektif Hadis, 42. syara'. ${ }^{24}$ Dan ada pula yang menetapkan hanya 3 syarat bahkan sampai 15 syarat oleh al-Khatib. ${ }^{25}$

Dalam perbedaan penentuan syarat tersebut, meskipun berbeda dalam hal jumlahnya, namun tidak memiliki perbedaan yang berarti, ada yang merincikannya dan ada yang tidak, bahkan saling melengkapi satu sama lain, serta memiliki asas dan tujuan yang sama. Berikut penjelasan syaratsyarat hakim yang ditentukan oleh Islam:

a. Beragama Islam

b. Laki-laki

c. Baligh dan Berakal

d. Kredibilitas Individu (Adalah)

e. Sempurna Panca Indera

f. Berpengatahuan Luas

Sedangkan dalam UU Peradilan Umum dan UU Peradilan Agama apabila memenuhi syarat-syarat yang telah ditetapkan undang-undang maka seseorang dapat ditetapkan menjadi seorang hakim. adapun syarat-syarat adalah sebagai berikut:

1) Warga Negara Indonesia

2) Bertaqwa kepada Tuhan Yang Maha Esa

3) Setia kepada pancasila dan Undang-Undang Dasar 1945

4) Bukan bekas organisasi terlarang Partai Komunis Indonesia

5) Pegawai Negeri

6) Sarjana Hukum (bagi Peradilan Agama, harus sarjana syari'ah dan/atau sarjana hukum yang menguasai hukum Islam)

7) Berumur paling serendahrendahnya 25 (dua puluh lima) tahun

24 Abdul Manan, Etika Hakim dalam Penyelenggaraan Peradilan: Suatu Kajian dalam Sistem Peradilan Islam (Jakarta: Prenada Media Group, 2007), 21.

${ }^{25}$ M. Hasbi Ash Shiddiqy, Peradilan dan Hukum Acara Islam, 35. 
8) Berwibawa, jujur, adil, dan berkelakuan tidak tercela.

9) Dalam UU Peradilan Agama ditambah satu syarat yaitu harus beragama Islam.

\section{Pandangan Fuqahā Kedudukan Hakim Wanita \\ Tentang}

Perdebatan di kalangan ulama fiqh tentang kedudukan hakim wanita yang mengacu pada surat An-Nis $\bar{a}$ ' ayat 34 , ayat ini kerap dijadikan dasar perempuan tidak diperkenankan berperan dalam wilayah publik, selain juga adanya hadis nabi yang melarang perempuan menjadi imam shalat bagi laki-laki. Dalam sejarah Islam, sejumlah sahabat perempuan di kenal pernah memerankan fungsi sebagai rujukan dalam hukum, layaknya seorang hakim. di antaranya adalah Aisyah RA, Ummu Salamah, Syafiyah, dan juga Ummu Habibah. Menurut mayoritas ulama madzhab Syafi'iyah, Hanabilah, dan Malikiyah, seorang perempuan dinyatakan tidak boleh memegang jabatan sebagai hakim. ketentuan ini berlaku di semua jenis kasus. Baik yang berkenaan dengan yang bersengketa harta, qishās ataupun hadd, atau kasus-kasus lainnya. Bila mereka tetap diberikan kepercayaan sebagai hakim, maka pihak pemberi wewenang kepada bersangkuta dihukumi berdosa. Ketetapan yang dihasilkan oleh hakim perempuan itu pun dianggap batal walaupun mengangdung unsur kebenaran. Sedangkan, dalam pandangan madzhab Hanafiyah, hukumnya tak jauh beda dengan pendapat mayoritas, hanya saja ulama bermadzab Hanafiyah sedikit memberikan keleluasaan. Selama dianggap memenuhi syarat-syarat tertentu, maka mereka diperbolehkan berposisi sebagai seorang hakim. hal itu sebagaimana diriwayatkan oleh Syu'bah Asa, di bidang peradilan pun, tercapai ijma' bahwa hanya pria yang berhak menjadi hakim. tapi variasi pendapat bukan tak diberikan. Golongan Hanafiyah mengakui absahnya seorang hakim perempuan dalam peradilan di luar kasus hadd (masalah perzinahan, tuduhan zina, pencurian, perampokan). Sementara Ibnu Jarir membolehkan perempuan menjadi hakim untuk kasus apapun. ${ }^{26}$

Menurut Djazimah Muqoddas ada tiga aliran pemikiran yang membahas perempuan menjadi hakim, yaitu:

1. Pendapat yang melarang perempuan menjadi hakim

Pendapat ini dipelopori oleh jumhur ulama' yang terdiri dari madzhab Malikiyah, madzhab Syafi'iyah, dan madzhab Hanabilah. Golongan ini menjadikan laki-laki sebagai syarat mutlak bagi seorang hakim, ${ }^{27}$ bahkan menganggap putusan hakim tidak sah apabila diputuskan oleh hakim perempuan. $^{28}$ Pendapat yang lebih keras dan tegas dari golongan ini yaitu menyatakan bahwa bagi yang mengangkat perempuan menjadi hakim akan mendapat dosa. ${ }^{29} \mathrm{Hal}$ ini didasarkan pada argumen yang dijadikan dasar oleh para ulama', di antaranya yaitu: Pertama, Pemahaman tekstual terhadap ayat-ayat al-Qur'an yang secara substantif telah memposisikan kaum laki-laki menjadi pemimpin bagi kaum perempuan.berdasarkan firman Allah surat an-Nisā' ayat 34

Kedua, terdapat hadits shahih ahad yang dari segi substansi matan haditsnya melarang perempuan sebagai kepala Negara yang diriwayatkan oleh

26 Arief Subhan, Syafiq Hasyim, dkk, Cuma Perempuan Dalam Islam: Pandanga Ormas Keagamaan, (Jakarta: Gramedia Pustaka Utama, 2003), 48

${ }^{27}$ Muhammad 'Abd. Al-Qadir Abu Faris, al-Qadha fil Islam (Aman: Dar al-Furqan, 1984), 78 .

28 Ibn Rusyd, Bidāyah al-Mujtahid wa Nihāyatul Muqtashid, (Kairo: Mesir, Mathba'ah Mustafa al-Babi al-Halabi, tt.), 344.

${ }^{29}$ Muhammad 'Abd. Rahman al-Bakr, alSultan al-Qadhaiyah wa Syahsiyah al-Qadi fi alNizam al-Islam, (Kaheran: al-Zahirahli al-I'lamal'Arabi, tt), 354. 
Bukhari, Tirmidzi, dan an-Nasa'i dari Abi Bakrah yang menyatakan:

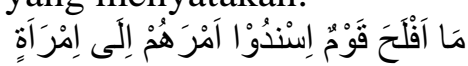
Artinya: "Tidak beruntung kaum yang menyerahkan kepemimpinannya kepada perempuan."

Ketiga, kondisi sosio-historis dan budaya pada masa sebelum dan awal datangnya Islam menunjukkan adanya suatu hegemoni budaya patriarki, yang mana kaum laki-laki diposisikan lebih tinggi daripada kaum perempuan. Sehingga peluang bagi kaum perempuan untuk jadi pemimpin lebih sempit ruangnya dari pada kaum laki-laki. $^{30}$

Keempat, ijma' ulama' mengenai larangan perempuan menjadi hakim dapat dibuktikan dari fakta lapangan di mana dalam sejarah Islam tidak ditemukan pemimpin dari kalangan perempuan. ${ }^{31}$

Kelima, larangan perempuan menjadi hakim diqiyaskan dengan larangan perempuan menjadi imam shalat dan menjadi khalifah. Disamping kelima alasan yang disebutkan di atas jumhur ulama' beranggapan bahwa perempuan memiliki banyak kelemahan dari berbagai aspek, misalnya kurang kecerdasan, wawasan, pergaulan, dan mengalami keterbatasan dalam berinteraksi dengan lawan jenis. Ibrahim al-Syirazi sependapat dengan jumhur ulama' dengan alasan bahwa "dengan perempuan menjadi hakim dikuatirkan akan mengundang fitnah, karena seorang hakim pasti akan hadir dalam majlis yang dihadiri oleh lakilaki sedang perempuan dilarang untuk menghadiri majlis seperti itu." Beberapa ulama' yang mendukung

${ }^{30}$ Ketiga alasan ini lihat pada Djazimah Muqoddas, Perempuan pada Peradilan Islam di Negara-Negara Muslim, (Yogyakarta: LkiS, 2001), 86-88.

31 Al-Baji, al-Muntaqa Syarh Muwatha' al-Imam Malik, j.5, (Beirut: Dar al-Kitab al'Araby, 1331), 182. pendapat jumhur ulama' di antaranya yaitu: Junaed al-Baghdadi, al-Mawardi, Ibnu Khaldun, Abu Ya'la, Bakri Syatha, Zakaria al-Ansari, Muhammad Battaji, dan Ibrahim al-Syirazi.

2. Pendapat yang membolehkan perempuan menjadi hakim hanya pada perkara perdata tidak pada perkara pidana.

Pendapat ini dipelopori oleh Imām Abū Hanīfah. Menurut pendapatnya, dia menolak penggunaan hadits tentang larangan perempuan memimpin dijadikan dasar sebagai larangan perempuan menjadi hakim, beliau beralasan bahwa kapasitas Nabi saat menyampaikan hadits tersebut bukan dalam kapasitas sebagai Nabi dan Rasul yang mendukung kebenaran wahyu, tetapi dalam kapasitas nabi sebagai manusia biasa yang mengungkap realitas sosial di masyarakat (bayan al-waqi') yakni mengantisipasi kemungkinan buruk yang terjadi kemudian hari apabila pemimpin diserahkan kepada perempuan. $^{32}$

Ibnu Hammam salah satu tokoh madzhab Hanāfiyah berpendapat bahwa laki-laki tidak menjadi syarat untuk menjadi hakim kecuali dalam masalah hudūd dan dima' (pidana). Larangan perempuan menjadi hakim pidana diqiyaskan dengan laranga perempuan menjadi saki pada kasus pidana, ${ }^{33}$ karena kapabilitas untuk menjadi hakim tergantung pada kapabilitas untuk menjadi saksi. Pendapat kalangan Hanāfiyah mengenai kebolehan perempuan menjadi hakim didasarkan pada nas alQur'an surat al-Taubah ayat 71 yang

32 Djazimah Muqoddas, Kontroversi Hakim Perempuan Pada Peradilan Islam di Negara-Negara Muslim, (Yogyakarta : LKiS, 2001), 90.

33 Wahbah az-Zuhaili, al-Fiqh al-Islamy wa Adilatuh, (Damaskus: Dār al-Fikr, 1989),5936. 
menyatakan kesetaraan laki-laki dengan perempuan.

Seiring dengan perkembangan hidup masyarakat yang ditandai dengan kemajuan ilmu pengetahuan dan teknologi, tampaknya beimplikasi pada corak pemahaman umat islam terhadap teks nash khususnya menyangkut eksistensi perempuan sebagai 'ibad Allah (hamba Allah) dan khalifat Allah fi al-Ardl (wakil Tuhan di dunia). Para ulama' yang mentolelir kebolehan perempuan diangkat sebagai pemimpin memahami bahwa menurut kaedah Ushul Fiqh, suatu nash baru dapat dikatakan menunjukkan larangan (keharaman) bila memuat setidaknya empat hal yakni: (1) secara redaksional, nash dengan tegas mengatakan haram; (2) larangan tersebut diungkapkan dalam bentuk nahyi; (3) nash mengandung ancaman (uqubah); (4) menggunakan redaksi lain yang menurut gramatika bahasa Arab menunjukkan tuntutan yang harus di laksanakan.

Namun dakam kenyataannya tidak ada dalil nash yang qoth'i secara tegas melarang perempuan untuk berkiprah di ranah publik, dalam hal ini sebagai hakim, dengan demikian baik laki-laki dan perempuan memiliki peran dan tanggung jawab yang sama dalam kancah politik di masyarakat, baik di tingkat legislatif, eksekutif maupun yudikatif. Demikian halnya dalam amar ma'ruf nahi munkar, perempuan boleh menjadi hakim. ${ }^{34}$ adapun lafadz qawwamuna yang terdapat dalam alQur'an surat al-Nisa' ayat 34 bermakna al-qawwamatul Usriyyah- pemimpin dalam keluarga. Hal ini berdasarkan asbabu al-nuzul ayat tersebut yang menunjukkan pada kepemimpinan keluarga, kepemimpipnan suami aras

\footnotetext{
34 Djazimah Muqoddas, Kontroversi Hakim Perempuan Pada Peradilan Islam di Negara-Negara Muslim, (Yogyakarta : LKiS, 2001), 220.
}

istri dalam mendidik dan mengarahkan keluarga menjadi keluarga yang sakinah, mawaddah dan rahmah. Beberapa ulama' yang mendukung pendapat ini, di antaranya yaitu: AsySyaukani dan Zamakhsari. ${ }^{35}$

3. Pendapat yang membolehkan perempuan menjadi hakim secara mutlak, mengadili baik pada perkara perdata maupun perkara pidana.

Pendapat ini dikemukakan oleh Ibnu Jarīr at-Thabarī, Ibnu Hazm dan Muhammad bin Hasan. ${ }^{36}$ Menurut Imam al-Baji, ada empat dalil yang dipergunakan sebagai dasar kebolehan perempuan menjadi hakim secara mutlak, yaitu di antaranya:

a. Al-Qur'ān surat at-Taubah ayat 71 yang menyatakan kesamaan peran dan tanggung jawab laki-laki dan perempuan. Namun terdapat pengecualian pada jenis kekuasaan tertentu yang tidak boleh diduduki oleh perempuan, yaitu kekuasaan Imamah 'uzma.

b. Hadits Rasulullah Saw. yang diriwayatkan oleh Ibnu Umar yang menyebutkan bahwa setiap orang adalah pemimpin, tanpa membedakan jenis kelaminnya. Rasulullah Saw. bersabda: :Setiap dari kalian adalah pemimpin, dan setiap kalian akan dimintai pertanggung jawaban terhadap apa yang kalian pimpin.” (HR. Muslim). Hal ini menunjukkan bahwa kaum perempuan berhak menjadi pemimpin dan hakim sebagaimana halnya kaum laki-laki.

c. Mengqiyaskan dengan hukum kebolehan perempuan menjadi mufti maka perempuan boleh

35 Djazimah Muqoddas, Kontroversi Hakim Perempuan Pada Peradilan Islam di Negara-Negara Muslim, (Yogyakarta : LKiS, 2001), 91.

36 Djazimah Muqoddas, Kontroversi Hakim Perempuan Pada Peradilan Islam di Negara-Negara Muslim, (Yogyakarta : LKiS, 2001), 220. 
menjadi hakim, sebagaimana pendapat Ibnu Jarīr yang menyatakan perempuan boleh menjadi hakim sebagaimana ia boleh menjadi mufti.

d. Jenis kelamin laki-laki bukan merupakan hal yang penting, sehingga keabsahan sebagai hakim tidak harus berjenis kelamin lakilaki. $^{37}$

Selain keempat alasan di atas, Imām Ibnu Jarīr at-Thabarī dab Imam Ibnu Hazm menambahkan alasan lainnya, yaitu: (1) Tidak ada satupun ayat al-qur'an maupun hadits yang secara terang melarang perempuan menjadi hakim, adapun pernyataan al-qur'an surat an-Nisā' ayat 34 adalah dalam hal kewajiban nafkah dan usaha suami terhadap istri, bukan dalam hal kepemimpinan secara luas; ${ }^{38}$ (2) Secara historis pernah terjadi pengangkatan auditor pasar pada masa khalifah Umar bin Khattab, bernama al-Syifa' dari suku alShuq. Beberapa tokoh ulama' yang mengikuti pendapat ini di antaranya, yaitu: Ibnu Jarīr atThabarī, Ibnu Hazm, M. Quraish Shihab, Husen Muhammad. ${ }^{39}$

\section{Biografi Imām Abū Hanifah}

Abū Hanīfah dilahirkan pada tahun 80 Hijriah (696 M) dan meninggal di Kufah pada tahun 150 Hijriah $(767 \mathrm{M})$. Nama beliau dari kecil ialah Nu'man bin Tsabit bin Zauta bin Mah. Ayah beliau keturunan dari bangsa Persi (Kabul-Afganistan), tetapi sebelum beliau dilahirkan, ayahnya

37 Djazimah Muqoddas, Kontroversi Hakim Perempuan Pada Peradilan Islam di Negara-Negara Muslim, (Yogyakarta : LKiS, 2001), 223

38 Muhammad Ibnu Jarir At-Thabari, Jami' al-Bayan, 290.

39 Djazimah Muqoddas, Kontroversi Hakim Perempuan Pada Peradilan Islam di Negara-Negara Muslim, (Yogyakarta : LKiS, 2001), 230 . sudah pindah ke Kufah. Oleh karena itu beliau bukan keturunan bangsa Arab asli, tetapi dari bangsa Ajam (bangsa selain bangsa Arab) dan beliau dilahirkan di tengah-tengah keluarga berbangsa Persia. ${ }^{40}$ Bapak Abū Hanīfah dilahirkan dalam Islam. Bapaknya adalah seorang pedagang, dan satu keturunan dengan saudara Rasulullah SAW. Neneknya Zauta adalah suku (Bani) Tamim. Sedangkan ibu Hanifah tidak dikenal di kalangan ahli-ahli sejarah tetapi walau bagaimana pun juga ia menghormati dan sangat taat kepada ibunya.

Kitab-kitab yang ditulisnya sendiri antara lain : (1) al-Farāidh: khusus membicarakan masalah waris dan segala ketentuannya menurut Islam, (2) asySyuruth: membahas tentang perjanjian, (3) al-Fiqh al-Akbar: membahas ilmu kalam atau teologi dan diberi syarah (penjelasan) oleh Imam Abu Mansur Muhammad alMaturidi dan Imam Abu al-Muntaha alMaula Ahmad bin Muhammad alMaghnisawi.

\section{Biografi Ibn Jarīr At-Thabarī}

Nama lengkap Ibn Jarīr At-Thabarī ini adalah Muhammad Ibn Jarir Ibn Yazid Ibn Khalid At-Thabari, ${ }^{41}$ ada yang menyatakan Muhammad Ibn Jarir Ibn Yazid Ibn Katsir Ibn Galib At-Thalib, ${ }^{42}$ ada juga yang menyebut Muhammad Ibn Jarir Ibn Yazid Ibn Katsir al-Muli AtThabarī yang bergelar Abu Ja' far. ${ }^{43}$

At-Thabarī lahir di Amul, sebuah wilayah provinsi Thabaristan pada tahun

40 Moenawir chalil, Biografi Empat Serangkai Imam Mazhab Hanafi, Maliki, Syafi'i, Hambali, (Jakarta : Bulan Bintang, 1955), Cet. ke-9, 19.

${ }^{41}$ Muhyidin Khalil al-Misi, Tarjamatu Ibn Jarir At-Thabari Jami'ul Bayan an Ta'wil Ayy Alqur'an, (Beirut : Dar al Fikr, 1984), jilid 1, 3.

${ }^{42}$ Husain Muhammad Az-Zahabi, At-Tafsir Wal Mufassirun, (Beirut : Dar al-Kutub, 1984), jilid 1. 3 .

43 Syamsudin Muhammad Ibn Ali Ibn Ahmad ad-Dawudi, Tabaqat al-Mufassirin, (Maktabah Wahbah, 1972) jilid 2. 106. 
$224 \mathrm{H} / 838 \mathrm{M}$ (ada juga yang menyatakan tahun $225 \mathrm{H} / 839 \mathrm{M}$ ) kemudian ia hidup dan berdomisili di Baghdad hingga wafatnya, yaitu pada tahun $310 \mathrm{H} / 923 \mathrm{M}$, pada hari Sabtu, kemudian dimaqamkan pada hari Ahad di rumahnya pada hari keempat akhir Syawal $310 \mathrm{H}$, (ada yang berpendapat wafatnya Ahad dan dimaqamkan hari Senin hari kedua akhir bulan Syawal) dan ada juga yang berpendapat hari ke tujuh akhir bulan Syawal.

Ayah At-Thabarī, Jarir Ibn Yazid adalah seorang ulama, dan dialah yang turut membentuk At-Thabarī menjadi seorang yang menggeluti di bidang agama. Ayahnya pulalah yang memperkenalkan dunia ilmiah kepada AtThabarī dengan membawanya belajar pada guru-guru di daerahnya sendiri, mulai dari belajar al-qur'an dan ilmu-ilmu agama lainnya. Dengan ketekunan dalam belajar At-Thabarī hafal al-Qur'an pada usia 7 tahun, kemudian pada usia 8 tahun sering dipercaya masyarakat untuk menjadi imam shalat dan pada umur 9 tahun ia mulai gemar menulis hadits Nabi. Hasil karya Imām At-Thabarī antara lain:

1) Kitab Adabul Qodho' (Al Hukkam)

2) Kitab Adabul Manasik

3) Kitab Adab an-Nufuus

4) Kitab Syarai' al-Islam

5) Kitab Ikhtilaful Ulama' atau Iktilaful Fuqoha' atau Ikhtilafu Ulama'il Amshor fi Akhkami Syaroi'il Islam.

6) Kitab Al Basith,

7) Kitab Tarikhul Umam wal Muluk (Tarikhul Rusul wal Muluk).

8) Kitab Tarikhul Rijal minas Shahabah wat Tabi'in.

9) Kitab at-Tabshir.

10) Kitab Tahdzib Atsar wa Tafsiilust Tsabit 'Ani Rasulullah Saw Minal Akhbar. 11) Kitab Al Jami' fiel Qira'at

12) Kitab Haditsul Yaman
13) Kitab Ar Rad 'Ala Ibni ‘Abdil Hakim

14) Kitab az-Zakat

15) Kitab Al 'Aqidah

16) Kitabul fadhail

17) Kitab Fadhail Ali Ibni Thalib,

18) Kitab Mukhtashar Al Faraidz;

19) Kitab Al Washaya,.

\section{Hakim Wanita dalam Pandangan Imām Abū Hanīfah}

Imām Abū Hanīfah menjelaskan bahwa wanita boleh diangkat sebagai kadi untuk memutuskan perkara yang menerima persaksian wanita, dan tidak boleh memangku jabatan kadi dalam masalah yang menerima persaksiannya. Jika ada penguasa yang mengangkat wanita sebagai hakim, maka pengangkatannya itu sah tetapi orang yang mengangkatnya memangku dosa. Demikian juga putusan yang dijatuhkan oleh kadi wanita itu tetap dianggap sah, kecuali kasus-kasus hudūd dan qishās. Hujah golongan yang menyetujui pendapat madzhab Abū Hanīfah ini didasarkan kepada qiyas, bahwa wanita boleh juga bisa menjabat sebagai kadi dalam berbagai perkaraperkara yang diharuskan wanita bisa menjadi saksi. ${ }^{44}$ Larangan wanita menjadi hakim pidana diqiyaskan dengan larangan wanita menjadi saksi pada kasus pidana, karena kapabilitas untuk menjadi hakim tergantung pada kapabilitas untuk menjadi saksi. $^{45}$

Imām Abū Hanīfah menghubungkan pendapatnya itu dengan hukum kesaksian. Menurut beliau seti ap orang yang dapat diterima kesaksiannya dalam kasus tertentu, maka untuk menjadi hakim pun tidak dibolehkan. Di sini terlihat jelas suatu hubungan hukum yang

44 Abdul Manan, Etika Hakim dalam Penyelenggaraan Peradilan: Suat Kajian dalam sistem Peradilan Islam, (Jakarta: Kencana, 2007), 24.

\footnotetext{
${ }^{45}$ Wahbah az-Zuhaili, al-Fiqh al-Islamy wa
} Adilatuh, (Damaskus: Dār al-Fikr, 1989), 5936. 
erat antar kebolehan menjadi hakim dengan kebolehan menjadi saksi. ${ }^{46}$

\section{Hakim Wanita dalam Pandangan Ibn Jarīr At-Thabarī}

Ibnu Jarīr berpendapat bahwa perempuan boleh menjadi hakim secara umum sama seperti kesempatan yang diperoleh oleh pria. Dalil yang digunakan beliau adalah: ${ }^{47}$

1. Tidak satupun ayat al-Qur'ān maupun pernyataan dari Rasulullah (hadis) yang secara tegas melarang perempuan menjadi hakim. oleh karena itu, setiap orang yang mampu untuk memutuskan perkara di antara manusia dengan baik, maka berhak menjadi hakim termasuk perempuan. Dan sifat feminisme tidak mempengaruhi pemahaman terhadap argumen-argumen dan pedoman hukum. ${ }^{48}$

2. Menurut Ibn Jarīr at-Thabarī, secara historis pernah terjadi pengangkatan perempuan sebagai hakim oleh khalifah Umar ibn Khattab pada masa pemerintahannya dengan mengangkat seorang perempuan bernama al-Syifa' sebagai orang yang memberikan keputusan di pasar. ${ }^{49}$

3. Analogi keabsahan fatwa perempuan yang dianggap sah, sehingga keputusannya sebagai hakim pun tentu saja dianggap sah. ${ }^{50}$

46 Syeikh Abdurrauf As Singkili, Corak Pemikiran Hukum Islam: Studi Terhadap Kitab Mir'at al-Thullab Tentang Hakim Perempuan, (Banda Aceh: Yayasan Pena, 2008), 61.

${ }^{47}$ Imam al-Qurtubi, Al-Jami' li Ahkam AlQur'an, (Qairo: Dar al-Mishriiyah, 1964 M), 32.

48 Al-Marshafawi, Nizham Al-Qadha fi AlIslam, Muassasah al-Risalah (1989 M), 32.

49 Wanita itu bernama al-Syifa binti Abdullah, perempuan yang telah masuk islam sebelum hijrah dan termasuk sahabat yang melakukan ba'iat dan orang-orang yang berhijrah pada periode pertama, termasuk perempuan intelektual pada masa Nabi Saw. lihat Ibn Hajar, Al-Ishabah, (Beirut: Dar al-Kutub al-Ilmiyyah, 2003), jilid 3, 144

${ }^{50}$ Ibnu Qudamah, Al-Mughni Ma'Al-Syarh Al-Kabir, (Al-Manar, 1347 H), Jilid 11, 380.
Persamaan pendapat antara pemikiran Imām Abū Hanīfah dan Ibn Jarīr AtThabarī mengenai kedudukan hakim wanita

Lembaga yudikatif berjuang dengan menyelesaikan sengketa setiap orang yang berperkara dengan seadil-adilnya. Lembaga eksekutif berjuang dengan menjalankan roda pemerintahan dengan sebaik-baiknya. Berkenaan dengan hal tersebut, baik laki-laki maupun perempuan juga memiliki kewajiban yang sama untuk 'amar ma'ruf nahyi munkar, sebagaimana dalil al-qur'an dalam surat at-Taubah ayat 71, disebutkan kesetaraan perempuan dan laki-laki. Dalil ini digunakan oleh Abū Hanīfah sehingga perempuan boleh menjadi hakim.

Begitu pula oleh Ibnu Jarīr atThabarī mengemukakan dengan salah satu dalilnya yaitu, ayat-ayat al-Qur'an dan hadits-hadits Nabi Saw. menetapkan bahwa orang-orang muslim, laki-laki dan perempuan, sebagian mereka adalah pemimpin bagi sebagian yang lain. Dan menurut asalnya perkara adalah "persamaan" di antara kaum laki-laki dan perempuan. Dalil kesetaraan yang digunakan oleh Ibnu Jarīr adalah dalil alQuran surat at-Taubah ayat 71 .

Jadi persamaan pendapat antara pemikiran Imām Abū Hanīfah dan Ibn Jarīr at-Thabarī dalam hal kedudukan hakim wanita yaitu diperbolehkannya seorang wanita menjabat sebagai hakim dan keduanya sama-sama tidak menjadikan laki-laki sebagai syarat mutlak untuk menjadi hakim.

\section{Perbedaan pendapat antara pemikiran Imām Abū Hanīfah dan Ibn Jarīr At- Thabarīmengenai kedudukan hakim wanita}

Adapun perbedaan yang signifikan di antara pendapat Abū Hanīfah dan Ibnu Jarīr at-Thabarī adalah di mana setelah dijabarkan dari bab-bab sebelumnya, Abū Hanīfah membolehkan seorang wanita menjadi hakim hanya menangani pada 
perkara perdata tidak pada perkara pidana. Abū Hanīfah mengqiyaskan kebolehan wanita menjadi hakim dengan kebolehan wanita menjadi saksi. ${ }^{51}$ Kecuali kasuskasus hudūd dan qisīs, karena kapabilitas untuk menjadi hakim tergantung pada kapabilitas untuk menjadi saksi. ${ }^{52}$ Abū Hanīfah mendasarkan pada qiyas, bahwa wanita boleh menjadi saksi dalam berbagai masalah, maka wanita bisa menjabat sebagai hakim dalam berbagai perkara-perkara yang diharuskan wanita bisa menjadi saksi. ${ }^{53}$

Sedangkan Ibnu Jarīr at-Thabarī adalah ulama' yang memperbolehkan seorang wanita untuk menjadi hakim secara mutlak dalam perkara perdata maupun pidana. Dalil yang oleh ulama terdahulu baik Imām Syafi'i maupun Imām Hanafī seperti Q.S. an-Nisā' ayat 34, Q.S. al-Baqarah ayat 282 dan hadits Rasul Saw yang diriwayatkan oleh Imām Ahmad, Bukhari, Nasa'i, dan Tirmidzi dan Abi Bakrah, semuanya ditolak oleh Ibnu Jarīr at-Thabarī. Karena menurut beliau tidak ada yang secara tegas mengatur tugas kehakiman. Logika yang di tempuh Ibnu Jarīr at-Thabarī dengan memberi ketentuan bahwa setiap orang yang boleh memberi fatwa, maka orang tersebut boleh pula memutuskan perkara (diangkat menjadi hakim), disini jelas ada kaitan yang erat seorang hakim dan seorang mufti.

Jadi perbedaan pendapat antara pemikiran imām abū hanīfah dan ibn jarīr at-thabarī mengenai kedudukan hakim wanita yaitu apabila imām abū hanīfah membatasi kewenangan hakim perempuan hanya pada wilayah perdata, berbeda

51 Syeikh Abdurrauf As-Singkili, Corak Pemikiran Hukum Islam: Studi Terhadap Kitab Mir'at al-Tullab Tentang Hakim Perempuan, (Banda Aceh: Yayasan Pena, 2008, 61.

52 Wahbah az-Zuhaili, al-Fiqh al-Islamy wa Adilatuh, (Damaskus: Dār al-Fikr, 1989), 5936.

53 Abdul Manan, Etika Hakim dalam Penyelenggaraan Peradilan: Suatu Kajian dalam Sistem Peradilan Islam, (Jakarta: Kencana, 2007), 24. halnya dengan ibn jarīr yang membolehkan perempuan menjabat sebagai hakim secara mutlak.

\section{Relevansi Pemikiran antara Abu Hanifah dan Ibn Jarir At-Thabari dalam Konteks keIndonesiaan}

Di Indonesia pada era sebelum tahun 1970 an, pendapat yang berkembang dan dianut kalangan ulama dan kemudian diamini oleh dunia hukum terkait partisipasi perempuan sebagai hakim di pengadilan agama masih di dominasi oleh pendapat fiqh madzhab Syafi'i dan beberapa madzhab besar lainnya, seperti Maliki dan Hanbali yang cenderung membatasi peran perempuan di bidang ini. Dominannya pandangan ini tentu bukan tanpa dasar, melainkan merupakan analisis pemahaman dari sejumlah nash, sumber hukum syari'ah, baik al-Qur'an maupun sunnah yang secara eksplisit mengisyaratkan pembatasan peran perempuan di ranah publik, khususnya pengadilan. Beberapa pandangan lain dari para ahli hukum islam klasik semisal Abu Hanīfah, Ibnu Hazm dan Ibnu Jarīr AthThabarī yang cenderung memberikan ruang lebih luas bagi keikutsertaan perempuan dalam ranah publik kurang mendapatkan respon positif dari kalangan intelektual muslim kala itu.

Namun demikian, di era setelah tahun 1970-an, seiring dengan bergulirnya isu gender yang kemudian mendapat respons dari kalangan pemikir islam Timur Tengah seperti Muhammad Abduh dan beberapa tokoh lainnya, mulai marak kajian-kajian yang mengangkat tema kesetaraan peran perempuan dalam berbagai bidang kehidupan bersama dengan kaum laki-laki. Dinamika ini memberikan pengaruh yang segnifikan bagi dunia peradilan di Indonesia terkait peran serta perempuan sebagai hakim di pengadilan. Terbitnya Undang-Undang Nomor 1 Tahun 1974 tentang Perkawinan dan Undang-Undang Nomor 7 Tahun 1989 tentang Peradilan Agama bisa 
dikatakan sebagai fase baru bagi keterlibatan perempuan dalam ranah publik yang lebih luas, khususnya di lingkungan peradilan agama. Peluang perempuan untuk menjadi hakim tampaknya mulai terakomodasi, baik dari segi regulasi maupun kompetensinya.

Pada dasarnya, yang harus dipahami dalam menganalisis suatu pendapat adalah bagaimana metode istinbath apa yang dipakai oleh kedua Imam dan cara pandang mereka terhadap nash, jika diperhatikan secara seksama dalam permasalahan ini, Imām Abū Hanīfah mewakili kelompok yang melihat teks secara utuh (tekstualis), sedangkan Imām Ibnu Jarīr at-Thabarī mewakili kelompok ulama yang melihat apa yang terkandung di dalam teks (kontekstual).

Oleh sebab itu, pendapat yang relevan di Indonesia khususnya adalah pendapat dari at-Thabarī yang menyatakan kebolehan hakim wanita. Terlebih dikuatkan oleh hukum positif mengenai kedudukan wanita sebagai hakim pengadilan agama diperbolehkan selama memenuhi kriteria yang diatur dalam Undang-Undang Nomor 7 Tahun 1989 dalam pasal 13 ayat (1). Kesempatan wanita saat ini terbuka lebar. Landasan hukum yang dapat dijadikan sumber hakim Pengadilan Agama boleh dijabat oleh perempuan adalah UUD 1945, Undang-Undang Nomor 7 Tahun 1989 tentang Peradilan Agama dan Al-Qur'an. Dengan demikian, seorang perempuan menduduki jabatan sebagai hakim Pengadilan Agama dengan syarat memenuhi kriteria yang telah diatur.

\section{E. KESIMPULAN}

Berdasarkan uraian dan pembahasan diatas yang telah dipaparkan sebelumnya, maka penyusun dapat mengambil kesimpulan sebagai berikut:

1. Menurut Imām Abū Hanīfah wanita dapat menjadi hakim hanya dalam masalah perdata (mu'āmalah) bukan dalam masalah pidana (qishās dan hudīd), sebagaimana mengqiyaskan kebolehan seorang wanita menjadi saksi begitupula kebolehan wanita menjadi hakim.

2. Menurut Ibnu Jarīr at-Thabarī wanita boleh menjadi hakim secara mutlak baik dalam perkara perdata (mu'āmalah) maupun pidana (qishās dan hudūd), Ibnu Jarīr at-Thabarī menganalogikan wanita boleh mengeluarkan fatwa yang dianggap sah, sehingga dalam hal ini wanita boleh menjadi hakim dan keputusannya pun dianggap sah.

3. Letak persamaan pandangan Imām Abū Hanīfah dan Ibnu Jarīr at-Thabarī dalam hal status wanita menjabat sebagai hakim yaitu baik Imām Abū Hanīfah maupun Ibn Jarīr at-Thabarī keduanya sama-sama tidak menjadikan laki-laki sebagai syarat sahnya pengangkatan seorang hakim. Imām Abū Hanīfah dan Ibnu Jarīr at-Thabarī. Berbeda pendapat dalam soal kewenangan hakim perempuan dalam memutuskan perkara pada wilayah peradilan, Imām Abū Hanīfah membatasi kewenangan wanita dalam memutuskan perkara hanya pada wilayah perdata tidak pada hudūd dan qishās. Selain itu, Imām Abū Hanīfah juga berpendapat bahwa orang yang mengangkat seorang wanita menjadi hakim, maka ia berdosa. Sedangkan Ibnu Jarīr at-Thabarī memperbolehkan wanita menjabat sebagai hakim secara mutlak dan terkait pengangkatannya pun secara mutlak ia memperbolehkan.

4. Di antara pendapat-pendapat kedua imam tersebut yang paling relevan di Indonesia adalah pendapat Ibnu Jarīr at-Thabarī sebagaimana dalam hal ini dinilai cocok sebagai pegangan Undang-undang kekuasaan kehakiman Republik Indonesia dan Undangundang ketatanegaraan dalam kajian keilmuan Agama Islam, sebagai landasan teori dan penetapan hukum 
yang sah mengenai kekuasaan kehakiman, serta untuk menghilangkan bentuk deskriminasi dan memberikan peluang kebebasan berfikir, menentukan arah, menentukan arah kebenaran serta menjamin hak-hak yang sesuai dengan ideologi pancasila terhadap bangsa Indonesia. Sehingga tercipta hukum dan undang-undang yang bisa diterima seluruh lapisan masyarakat Indonesia dan membentuk kemaslahatan secara universal.

\section{DAFTAR PUSTAKA}

Al-Baji, al-Muntaqa Syarh Muwatha' alImām Malik, j.5, Beirut: Dār alKitāb al-'Arabō, 1331.

Ash Shiddiqie, Teungku Muhammad Hasbi. Peradilan dan Hukum Acara Islam, Semarang: Pustaka Rizki Putra, 1997.

Ash shiddieqy, Muhammad Hasbi. Pokok-Pokok Pegangan Imam

Madzhab, cet. ke-1, Semarang: PT Pustaka Rizki Putra, 1997.

Az-Zuhaili, Wahbah. Al-Fiqh al-Islāmy wa Adilatuh, Damaskus: Dār alFikr, 1989.

Arief Subhan, Syafiq Hasyim, dkk, Cuma Perempuan Dalam Islam:

Pandangan Ormas Keagamaan, (Jakarta: Gramedia Pustaka Utama, 2003.

al-Qurtubi, Imam. Al-Jāmi' li Ahkām AlQur'ān, Qairo: Dār al-Mishriiyah, $1964 \mathrm{M}$

Al-Ghazali, Abu Hamid, Ihya Ulümu adDìn, juz ii.

Bisri, Cik Hasan. Peradilan Agama di Indonesia, Jakarta: PT. Raja Grafindo Persada, 2000.

Dahlan, Abdul Aziz (ed). Ensiklopedi Hukum Islam, cet. ke-1, Jakarta: PT Ikhtiar Baru Van Hoeve, 1996.

Muqoddas, Djazimah. Kontroversi Hakim Perempuan Pada Peradilan Islam di Negara-Negara Muslim, Yogyakarta : LKiS, 2001.
Munawwir, Ahmad Warson, Kamus alMunawwir Arab-Indonesia, Surabaya: Pustaka Progresif, 1997.

Ibnu Rusyd, Bidāyah al-Mujtahid wa Nihāyatul Muqtasid, Kairo: Mesir, Mathba'ah Musthafa al-Bab alHalabi wa Auladuh, 1973.

Mulia, Siti Musdah dan Anik Farida, Politik dan Perempuan, Gramedia Pustaka Utama, 2005

Yonggo, Huzaemah Tahido M.A, Prof.Dr.Hj. Fikih Perempuan Kontemporer. Penerbit Ghala Indonesia. Bandung.2010

Nasution, Khairuddin, Fazlur Rahmān Tentang Wanita, Yogyakarta, Tazzafa: 2001

UNDP INDONESIA, Partisipasi Perempuan dalam Politik dan Pemerintahan, UNDP Indonesia, Mei, 2010

Rochim, Abdul, Hakim Perempuan : Perspektif Imām Abū Hānifah dan Imām Syāfi'i, Skripsi UIN Sunan Kalijaga, 10 September 2010

Trigiyatno, Ali, Pandangan Ibnu Jārir At thābari tentang Kedudukan Wanita Sebagai Hakim dan Imam Sholat, Muwazah, volume 6, nomor 2. Desember 2014

Suqayyah, Abdul Hakim Abu, Kebebasan Wanita, Jakarta, Gema Insani Press, 1997

Thahar, Kamarisah, Hak Asasi Perempuan dalam Islam, Medan: Ofset Maju, 1982

Qudamah, Ibnu, Al-Mughn̄̄ Ma' Al-Syarh Al-Kabīr, Al-Manar, Jld. 11, 1347 $\mathrm{M}$

Zaidan, Abd' Al-Karim, Nizām Al-Qadā fi al-Asyari'ah al-Islāmiyyah, Baghdad: Matba'ah Al-Aini, 1984

Zuhriah, Erfaniah, Peradilan Agama di Indonesia dalam Rentang Sejarah dan Pasang Surut, Malang, UIN Malang Press, 2008

Manan, Abdul. Etika Hakim dalam Penyelenggaran Peradilan, Suatu 
Kajian dalam Peradilan Islam, Jakarta: Kencana, 2007.

Madzkur, Muhammad Salam. Al-Qadā fi Al-Islam, terjemahan Imron AM dengan judul Peradilan dalam Islam, Surabaya: PT Bina Ilmu, 1993.

Ibnu Hammam, Mu'in al-Hukkām Fimā Yataraddadu Baina al-Khasamain min al-Ahkām, j.7, Mesir: Maktabah al-Musthafa al-Bāb al-Halabi wa Auladuh, 1973.

Zein, Fuad, dkk., Studi Perbandingan Madzhab, Yogyakarta: Pokja Akademik UIN Sunan Kalijaga Yogyakarta, 2006.

Nuruddin Al-Khamidi, Al-Ijtihād alMaqhāsidi Dhawābituhū wa Majālatuhu, (Mesir: Riasah alMuhakkam al-Syar'iyyah)

Rosyidah, Hermawati Ida. Relasi Gnder Dalam Agama-Agama, UIN Jakarta press. 2013.

Jainal Arifin, MA, Peradilan Agama dalam Bingkai reformasi hukum di Indonesia

Fayumi, Badriyah. Isu-Isu Gender Dalam Islam, (PSW UIN Syarif Hidayatullah, 2002.

Bahnasawi, Salim Ali. Wawasan Sisten Politik Islam, Jakarta: Pustaka AlKautsar, 1996

Syafe'i, Rachmat. Ilmu Ushul Fiqih untuk UIN, STAIN, PTAIS, cet. ke-3, Bandung: Pustaka Setia, 2007Pusat Bahasa Departemen Pendidikan Nasional, Kamus Besar Bahasa Indonesia,

Jakarta: Balai Pustaka, 2002

Waluyo, Bambang. Implementasi Kekuasaan Kehakiman Republik Indonesia. (Jakarta : Sinar Grafika,1991

Broto, Al Wisnu. Hakim dan Peradilan di Indonesia (dalam beberapa aspek kajian), Yogyakarta: Penerbitan Universitas Atma Jaya, 1997

Asy-Syarqawi, Abdurrahman. Kehidupan Pemikiran dan Perjuangan Lima
Imam Madzhab Terkemuka, Bandung : al-Bayan. 1994), cet ke-1

Al-Misi, Muhyidin Khalil. Tarjamatu Ibn Jārir At-Thābari Jami'ul Bayān an Ta'wil Ayy Al-qur'ān, Beirut : Dār al Fikr, 1984, jilid 1

Az-Zahabi, Husain Muhammad. At-Tafsīr Wal Mufassirūn, Beirut : Dār alKutūb, 1984, jilid 1.

Syamsudin Muhammad Ibn Ali Ibn Ahmad ad-Dawudi, Tabaqāt alMufassirin, Maktabah Wahbah, 1972, jilid 2

Direktorat Jendral Badan Peradilan Agama, Undang-Undang No. 3 tahun 2006 tentang Perubahan Atas Undang-Undang No. 7 tahun 1989 tentang Peradilan Agama, Jakarta: Badilag, 2006.

Bastoni, Hendri Andi. 101 Kisah Tabi'in, Jakarta : Pustaka al-Kautsar, 2006, cet ke-1.

Trigiyatno, Ali. Pandangan Ibnu Jarir At Thabari tentang Kedudukan Hakim Wanita sebagai Hakim dan Imam Sholat, Muwazah, volume 6, nomor 2, Desember 2014. 